\title{
EXPLORING ON THE MUSICAL QUALITIES AND SYMBOLS IN LANDSCAPE ARCHITECTURE
}

\author{
Fereshteh Kharrazi Qadim ${ }^{1 *}$ \\ ${ }^{1}$ Young Researchers and Elite club, Tabriz Branch, Islamic Azad University, Tabriz, Iran \\ *Corresponding Author: Fereshteh Kharrazi Qadim, F.kharrazi.arch@gmail.com
}

\begin{abstract}
Music causes a sensation by some of the principles and arranged sounds to the hearer. These feelings are qualities that are presented in this essay in landscape architecture and the principles that provide them which are analyzed in organizing mode.

The method of research in this essay is descriptive-analysis and these qualities are analyzed in different tables and the results which are achieved by analysis is that the qualities of music, the symbols in landscape architecture, organizing them and providing beautiful places which are suitable in the landscape atmosphere are used and shown. Some of Qualities and symbols of landscape architecture and their characteristics, atmosphere of them and also principles of organizing landscape have been studied. As beautiful and euphony composition of music can lead to tranquility in the listener, uphold the principles of aesthetic for the building can also create an eye-catching and beautiful structures. In this study has been tried to be paid to common principles that cause the beauty of music and architecture of buildings.
\end{abstract}

Keywords Musical Symbols, Musical Qualities, Principles of Organizing, Landscape, Architecture

\section{PEYZAJ MIMARLIĞI MÜZIK NITELIKLERI VE SEMBOLLER KEŞFETMEK}

ÖZ

Müzik dinleyenin sesler ilkelerin bazıları tarafından bir hissi neden olur ve düzenlenmiş. Bu duygular peyzaj mimarisinde bu yazıda sunulmuştur nitelikleri ve modu organize analiz edilmektedir bunları sağlamak ilkelerdir.

Bu yazının araştırma yöntemi tanımlayıcı analizi ve bu nitelikleri farklı tablolarda analiz edilir ve analizi ile elde edilir sonuçlar müzik olduğunu nitelikleri, peyzaj mimarlığı semboller, uygun olan güzel yerler onları organize ve temin olduğunu peyzaj atmosfer kullanılan ve gösterilir. Nitelikleri ve peyzaj mimarlı̆̆ sembolleri ve özellikleri, bunların atmosfer ve aynı zamanda peyzaj düzenlenmesi ilkelerden bazıları çalışılmıştır. müziğin güzel ve ahenk kompozisyon dinleyici huzur yol açabilir gibi, aynı zamanda göz alıcı ve güzel yapılar oluşturmak bina için estetik ilkelerine uyulması. Bu çalışmada, müzik ve binaların mimari güzelliği neden olan ortak ilkeler ödenecek çalışılmıştır.

Anahtar kelimeler Müzik Semboller, Müzikal Özellikler, Organizasyon, Peyzaj, Mimarlık İlkeleri

\section{INTRODUCTION}

Music is a kind of art that is created with handling and mixing pleasant sounds and the beauty and attractiveness are calculated by considering the result of it on soul and mind of the audience [14]. This "Schopenhauer" phrase that "every kind of arts wants to reach the music level" includes the fact that the knowledge of it guides all of us to know the real meaning of all kinds of arts. The principles that are arisen are the presence of abruption and abstraction in the art of music [5].

Most of the general people believe that the result of music is pleasant, lovely when they follow rules. The rules that have calculated and measured physic, the technique of them based on of ear and mind of human beings and on the musical instruments in thousands of years [5].

Beginning with a brief historical summary of the relationships among sound, music, and the forms of buildings, Sheridan and Karen[26], argue for the inclusion of broader-based design criteria in the academic design studio and professional practice. This expanded basis for design and criticism includes an 
understanding and appreciation of the aural character of buildings. They believe, to the extent that sound can be integrated into the design and evaluation process, the sonic aspect of buildings can be intentionally articulated to achieve a richer, more satisfying built environment: one that responds to the ear as well as the eye. Also in another study, Hanoch[8] focused on certain musical and architectural words created during the second the very categorizations of temporal versus spatial arts. In particular, they discusse the reversion urban design, and the transformation of the linear process of the musical score into a modular one, leading the performer to a process similar to that of performing or comprehending an architectural work. In their study, works of composers such as Ligeti, Stockhausen and Cage, whom resuscitate the frozen time into fluid architecture by use of Plan and Graphic score are discussed as well as similar scoring techniques in other arts such as poetry, dance and urban design. Like the Greek people used to imagine music geometrical that are changed to sound, the architects of renaissance also believed that architecture is mathematic that is revised to spatial units [3].

Landscape is the tangible form that it reflects the visual, usages and meanings of things in the atmosphere. This word refers to the meaningful reflection of mixed elements and factors that exist outside the mental effects of the observer [9].

Since the main feeling of us from our environment is visual feeling, the designer should be expert in using the visional movements. Also he should be able to strengthen the visual feelings. Otherwise, the resulted feeling will be weak. By using the sensational motives, the designer can create a strong feeling of place [23].

These sensational motives of visual feelings are provided by factors that organize the atmosphere. In this essay we will analyze the principles of organizing in landscape architecture due to the beauty of the music qualities.

\section{MUSICAL QUALITIES}

All of us know that before anything, music is produced with sound or voice. In other words without sound there won't be any music [10]. The placement of sounds and silence next to each other will cause a music composition in the end $[21,25]$.

Presence of arrangement in music, presence of relations and mathematical relations have the undeniable role in forming and notes of music. Another sign of presence of arrangement in music is the regular repeating of time. In Iranian music we face with the context of time with the forms of metric and rhythmic forms and in both forms of creating music, producing regular compositions are virtual when the presences of sound or not presence of it are followed by abstract forms [15].

One form of art is the shape and the appearance of the play. The purpose of form is analyzing the features of the appearance of the musical compositions. For example, a Suite in its creation has a special form that each of these forms has their own forms and the special form of each composition will produce Suite. In fact, the form of music is modeling the construction of the compositions and including the vocal melodies, forms of amount and rhythm, harmony and other factors of constructing the algorithm of a work and composition. The factors of repeating and symmetrizing, variation or uniting (making proportion even between the contradictory elements) cold are known as the elements of form construction of music. Since the subject in music has a fundamental role, the numbers of chansons and forms in music are limited to simple and complicated [14].

\section{LANDSCAPE ARCHITECTURE, DEFINITIONS AND EXPRESSIONS}

The meaning of landscape in English is landscape and in French is Paysage. These two words that are come from the words land and pay mean nation and scape and sage refer to a glance to the future and mean a nation which is in far away and in Persian mean scenery, but in common language the word landscape is an expression [6], because the meaning of the word landscape has deep connotations. Observing is accompanied by thinking and the other meaning of landscape is looking the things available. As a result, landscape is an incident that is used according to atmosphere in order to build the external environment for smart human and their souls [17].

Landscape is a live creature that is the production of human relation with the environment and mind. This 
sentence "It is alive" means that it is always changing. It is obvious that in designing the landscapes with the purpose of creating different external atmospheres, paying attention to landscapes is fundamental [25]. The landscape architecture is a visual and mental event that is shaped in external atmosphere. It appears in the minds of human beings and in other words is the production of vision and mind. So the landscape architecture is not only forming the atmosphere and is in connection with mind and due to the changes of the time and related to people's beliefs, it varies [11].

The purpose of landscape architecture is humanizing the atmosphere and organizing the visual atmosphere. In other words the other purpose of landscape architecture is designing the external atmosphere that has important meanings compared with constructions [1].

Landscaping refers to every activity that changes the significant features of an area on the earth. Such as:

1) Live elements: like planting of the earth, animals or what are called gardening which means the art of growing the plants with the purpose of producing a beautiful atmosphere in the landscape

2) Natural elements: such as the forms of the earth, the forms of plain forms, the forms of heights and water

3) Human elements: including different forms of land that are produced or installed with human beings, such as structures, constructions, fences or any other materials

4) Permanent elements: like air and light condition

5) Transitory elements such as lighting and weather conditions

Landscaping is knowledge and art and requires well observation and designing skills. A landscaping designer feels the produced elements and combines them [24].

Every atmosphere is a landscape if they are used, otherwise they cannot be called landscape.

\section{QUALITIES AND PRESENCES OF LANDSCAPE ARCHITECTURE}

Designing new places or rebuilding the new or old places, the landscape architects follow the moral, ecological, social, beauty and philosophy models. The qualities that are represented in the following are the results of designing experience and are effected widely by the environment and social philosophy and also designs of beauty feeling [4]. Here, I mentioned seven symbols and quality of landscape architecture and details of each of them is given in the table 1.1 and 2.

\section{ASPECTS OF SENSATIONAL FEELINGS OF LANDSCAPE ARCHITECTURE}

Feeling is experiencing with sensational organs. Feelings are mental constructions that include knowing and judging. So the sensational feeling of a place is imaged in the audience mind in the result of physical synergy [13].

Table 1.1. Qualities and symbols of landscape architecture and their characteristics.

\begin{tabular}{cl}
\hline $\begin{array}{c}\text { Qualities of } \\
\text { Designing } \\
\text { Landscape }\end{array}$ & Characteristics \\
\hline Response & - Using the experiences of people in landscapes \\
& - Feeling the processes and natural systems, protection, upgrade or \\
& repairing them(replying people, nature and the environment) \\
Originality $\quad$ - The thing that places should be & - The feeling of the places like they are \\
& (thing that a certain context can change) \\
Recycling $\quad$ Recycling and trapping materials, construction and planting & - Developing the purposes of landscape \\
& Submit Date: 05.04 .2016$, Acceptance Date: 24.07.2016, DOI NO: 10.7456/1060AGSE/074 \\
Copyright $\odot$ The Turkish Online Journal of Design, Art and Communication
\end{tabular}


The Turkish Online Journal of Design, Art and Communication - TOJDAC August 2016 Special Edition

- Advantages of environment and beauty discoveries of planting

- Advantages and meanings of a landscape

(discovering the advantages of site and feeling them for more information of development)

Uniting and Power - Using activities and different experiences for large amounts of people

- Using them at the same time

(as a united powerful whole, widespread and flexible)

Mysterious, - Being mysterious: searching the places for combining them.

Clearness, - Clearness: easiness of a place in reading and building

Complexity and - Complexity: varieties the components in a place

Arrangement - Arrangement: the places being related

(Emphasis on the whole characteristics for easy guidance at the same time)

Table 1.2. Qualities and symbols of landscape architecture and their characteristics.

Qualities of Characteristics
Designing
Landscape

\begin{tabular}{cl}
\hline Uniqueness and & - Having uniqueness, not existence of varieties = permanent \\
Variety & - Various, without uniqueness = messy \\
& (in search of a balance between uniqueness and variety considering \\
& variation for raising the people's emotions) \\
& - The qualities of uniqueness and maturity(completing and putting \\
& together the different parts and the whole forms and components of \\
landscape)
\end{tabular}

The methods of improving sensation:

- Improving sensation through material technique.

- Improving the sensation through using the whole sensational organs through color, surface and volumes.

- Improving the sensation through considering the large and powerful visual complexity.

- Improving sensation through providing miracles and visual mysteries.

- Improving sensation through commenting or reforming the suitable mental imaginations [27].

The factors of sensational improvement can be divided into two categories:

Physical factors: the meanings of fullness and emptiness, proportion, style, color, details.

Visual factors: Nature and constitutive elements of appearance, context and knowing typology of the greenbelt elements [27].

The feeling-cognition process can be explained as a process that the sensational motives change to mental elements. In this process several chapters are identifiable, such as identifying the model, form, referring to 
the meaning of form, entering the emotions in these contexts and at the end the audience behavior toward the last four parts. Since most of our perceptions from the environments are perceived by vision the designer should be expert in utilizing the visual motives to produce the certain feelings.

Table 2. Perception aspects of atmosphere and landscape. Source: Author adapted by [13]

\section{Sensational Time aspect}

\section{aspects}

The process of Mortal and passing definition of atmosphere and landscape moral feeling

\begin{tabular}{|c|c|c|c|c|}
\hline $\begin{array}{l}\text { Identifying } \\
\text { the model }\end{array}$ & $\begin{array}{l}\text { Atmosphere } \\
\text { and landscape } \\
\text { as rhythm }\end{array}$ & $\begin{array}{l}\text { Atmosphere and } \\
\text { landscape in } \\
\text { different periods } \\
\text { show the various } \\
\text { feelings. } \\
\text { These rhythms } \\
\text { are perhaps the } \\
\text { most purified } \\
\text { way of } \\
\text { describing } \\
\text { system } \\
\text { process which is } \\
\text { period } \\
\text { movements } \\
\text { toward the } \\
\text { genetic } \\
\text { nature. }\end{array}$ & $\begin{array}{l}\text { Daily } \\
\text { rhythms }\end{array}$ & $\begin{array}{l}\text { Day and night, defining the light and } \\
\text { darkness and the effect on perceiving } \\
\text { the atmosphere. } \\
\text { During sunrise and sunset } \\
\text { atmosphere and landscape looks flat } \\
\text { and loose color. At this moment the } \\
\text { observer becomes more sensitive to } \\
\text { not visual motives like sounds. } \\
\text { Finally at night from vision point of } \\
\text { view another landscape is created, } \\
\text { the distances look farther. Vision } \\
\text { observes the sky and the feelings of } \\
\text { hearing, smelling, tasting and } \\
\text { touching senses become more } \\
\text { powerful. }\end{array}$ \\
\hline $\begin{array}{l}\text { Identifying } \\
\text { the Form }\end{array}$ & & & $\begin{array}{l}\text { Season } \\
\text { rhythms }\end{array}$ & $\begin{array}{l}\text { Spring, summer, fall and winter are } \\
\text { the symbols of Birth, adolescence, } \\
\text { oldness and death. }\end{array}$ \\
\hline $\begin{array}{l}\text { Relating } \\
\text { the } \\
\text { meaning to } \\
\text { form }\end{array}$ & & & $\begin{array}{l}\text { Sequent } \\
\text { rhythm }\end{array}$ & $\begin{array}{l}\text { Atmosphere and landscapes are in } \\
\text { relation with sequent rhythms such as } \\
\text { pioneer, location, primary sequence, } \\
\text { secondary sequence and repeated } \\
\text { imagination. These rhythms are } \\
\text { relatively predictable and the } \\
\text { progress relate on the climate. } \\
\text { But the rhythms are unpredictable } \\
\text { yet, because regretting can interfere } \\
\text { with process in every time. So it can } \\
\text { be said that these rhythms are } \\
\text { performed as hay wire (according to } \\
\text { the messy theory that says the } \\
\text { realities are deprived from eternal }\end{array}$ \\
\hline
\end{tabular}




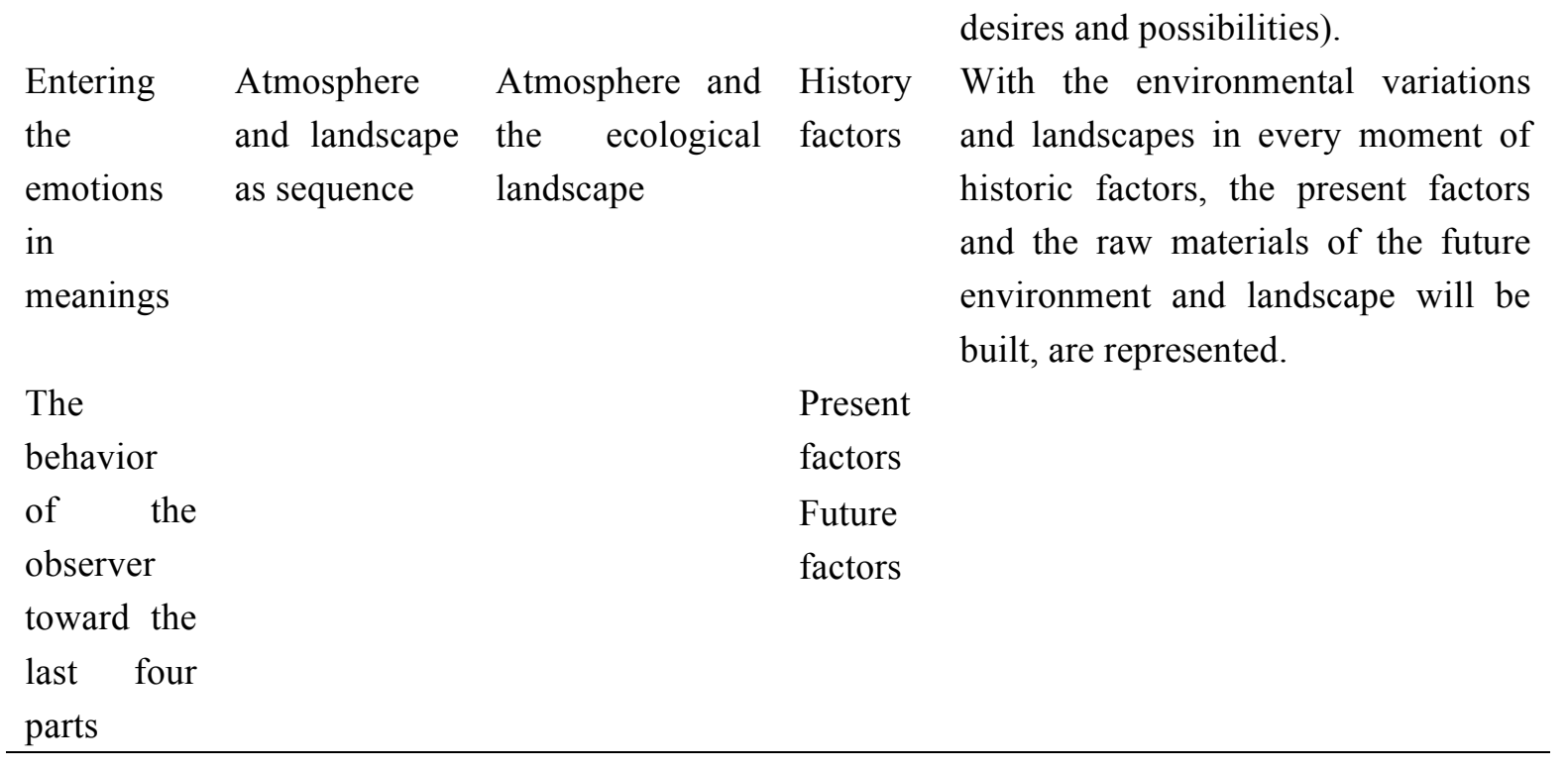

Furthermore, he should be able to improve the other visual feelings by other suitable motives [13].

Landscape is the other form of place and is the result of human connections and the environment in external atmosphere. Landscape is not produced accidentally, but it is produced by the experience of human beings and is produced slowly [12]. Urban landscape is a part of the shape of the city that the audience perceives it. In other words the shape of the city in urban landscape changes to the significant and direct quality. This means the urban landscape is the perceivable vision and the perceivable atmosphere existing in our city [7].

Urban landscape is the bundle of environmental motives. These motives send informations to the citizens that enable the environmental feeling in our mind. It is based on these information and feelings that the inhabitants of those atmospheres judge. These motives perceive the human beings sensations and the feeling process is processed by mind. This information not only consists of form, function and the meaning of atmosphere, but also consists of the distances of boarders. The opposite boarders and in fact, the boarders of atmospheres [22,] (Table 2).

Table 3.1. Table of the principles of organizing landscape architecture and their features and comparing them with musical features.

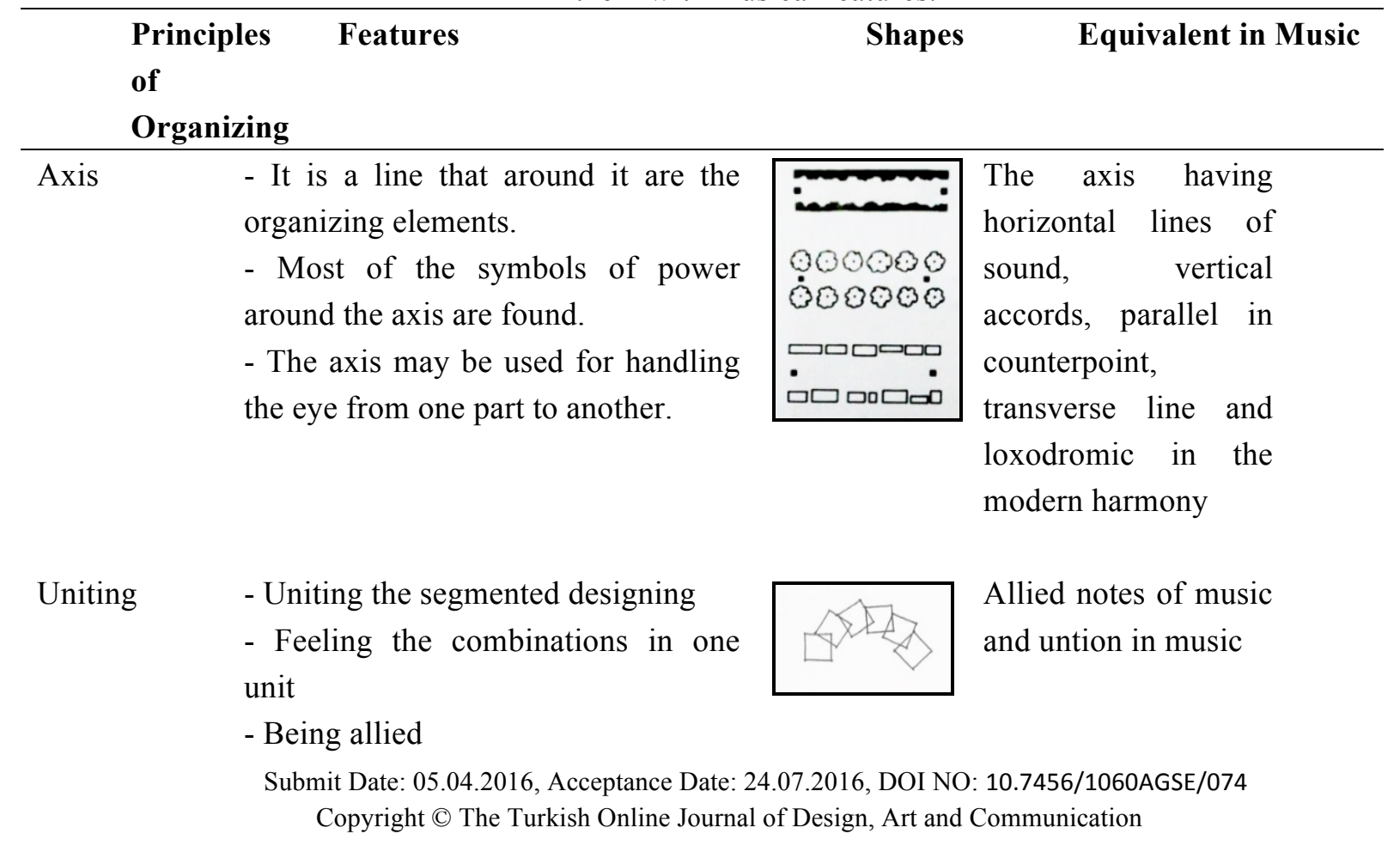


Arrangement - The manner of adaptability of elements to the atmosphere

- Related to elements relations

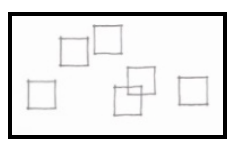

Harmony of arranged

sounds

(Harmonization)

\begin{tabular}{|c|c|c|c|}
\hline Attraction & $\begin{array}{l}\text { - Curiosity with the attention } \\
\text { - Various of forms, size, color and } \\
\text { change in direction, movement and } \\
\text { sound }\end{array}$ & $\begin{array}{l}\text { Anything } \\
\text { that has } \\
\text { visional } \\
\text { beauty and } \\
\text { produces } \\
\text { attraction }\end{array}$ & $\begin{array}{l}\text { Attraction in } \\
\text { music(the sound } \\
\text { attraction of the } \\
\text { around tones) }\end{array}$ \\
\hline
\end{tabular}

Table 3.2. Table of the principles of organizing landscape architecture and their features and comparing them with musical features.

\begin{tabular}{|c|c|c|c|}
\hline $\begin{array}{l}\text { Principles } \\
\text { of } \\
\text { Organizing }\end{array}$ & Features & Shapes & Equivalent in Music \\
\hline $\begin{array}{l}\text { Sequence of } \\
\text { Arrangement }\end{array}$ & $\begin{array}{l}\text {-In complicated combinations, } \\
\text { sequence of arrangement for } \\
\text { providing tidiness of the components } \\
\text { is essential. } \\
\text { - The algorithm of communicative } \\
\text { sequence is in order. }\end{array}$ & A & $\begin{array}{l}\text { Sequence of } \\
\text { arrangements in } \\
\text { musical forms and } \\
\text { keeping the notes } \\
\text { orders }\end{array}$ \\
\hline $\begin{array}{l}\text { Differences } \\
\text { and } \\
\text { Variations }\end{array}$ & $\begin{array}{l}\text { - The opposite of simplicity } \\
\text { - Enough and suitable variation that } \\
\text { produce attraction }\end{array}$ & & $\begin{array}{l}\text { Producing variations } \\
\text { at good times to } \\
\text { provide attractiveness } \\
\text { in music }\end{array}$ \\
\hline $\begin{array}{l}\text { Emphasis } \\
\text { and } \\
\text { Concentratio } \\
n\end{array}$ & $\begin{array}{l}\text { - Emphasis and Concentration are } \\
\text { domination of the most important } \\
\text { element in landscape. } \\
\text { - It is achieved by effective usage. } \\
\text { - A mass of aggregations among } \\
\text { small aggregations. } \\
\text { - Decoration and concentration on } \\
\text { the elements or components complete } \\
\text { the principles of emphasis. }\end{array}$ & & $\begin{array}{lr}\text { Metric } & \text { emphasis, } \\
\text { structural } & \text { emphasis } \\
\text { and } & \text { emotional } \\
\text { emphasis in music }\end{array}$ \\
\hline Balance & $\begin{array}{l}\text { - The state of cognitive equilibrium } \\
\text { - Balance includes permanence in } \\
\text { order to produce satisfaction and } \\
\text { security } \\
\text { - Balance in landscape compositions }\end{array}$ & 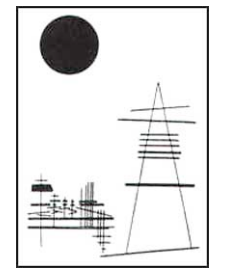 & Musical balance \\
\hline
\end{tabular}


usually means alignment depending

on the vertical axis and the vision.

Table 3.3. Table of the principles of organizing landscape architecture and their features and comparing them with musical features

\begin{tabular}{|c|c|c|c|}
\hline Principles & Organizing & Shapes & Equivalent \\
\hline Symmetry & $\begin{array}{l}\text { - The symmetry may be axis or center like. } \\
\text { - The resonance combinations are } \\
\text { permanent and calm. }\end{array}$ & & $\begin{array}{l}\text { - Symmetry in } \\
\text { musical bearer } \\
\text { - Symmetry in } \\
\text { amounts and notes } \\
\text { - Symmetry in } \\
\text { themes and dignity }\end{array}$ \\
\hline Rhythm & $\begin{array}{l}\text { - Rhythm may be produced in every } \\
\text { dimension } \\
\text { - Rhythm can be complex and produced } \\
\text { of repeated shapes rather than one shape } \\
\text { - Rhythm causes better combination and } \\
\text { at the end causes improvement of } \\
\text { designing }\end{array}$ & 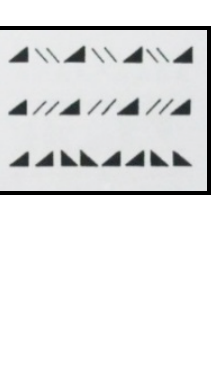 & $\begin{array}{l}\text { Rhythm and beat is } \\
\text { the intentional and } \\
\text { pleasant repeating in } \\
\text { music that is related } \\
\text { to time. }\end{array}$ \\
\hline $\begin{array}{l}\text { Criterion } \\
\text { and } \\
\text { Proportion }\end{array}$ & $\begin{array}{l}\text { Proportional comparing height, length, } \\
\text { area, volume and capacity }\end{array}$ & & $\begin{array}{l}\text { Presence of } \\
\text { mathematical } \\
\text { proportion and } \\
\text { comparing numbers } \\
\text { in music }\end{array}$ \\
\hline $\begin{array}{l}\text { Permane-n } \\
\text { ce }\end{array}$ & $\begin{array}{l}\text { - It can be related to space or time. } \\
\text { - In some algorithms a repeated shape in } \\
\text { a special size and criterion, represents } \\
\text { permanence.(Fractal geometry) } \\
\text { - Permanence shows ling term and } \\
\text { permanent structural that make the } \\
\text { scene to change }\end{array}$ & & $\begin{array}{l}\text { Permanence and } \\
\text { duration of musical } \\
\text { constructions in } \\
\text { some compositions } \\
\text { and accords }\end{array}$ \\
\hline Similarity & $\begin{array}{l}\text { - The more the elements are similar, the } \\
\text { more they are connected. }\end{array}$ & 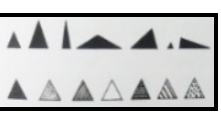 & $\begin{array}{l}\text { - Similarities in the } \\
\text { themes of music }\end{array}$ \\
\hline
\end{tabular}

Significant feelings of urban landscape are not only in visional elements, but also the sounds of the environment, smell and other impressive things on the feelings of human beings play role. On the other hand, landscape is not limited to our world and is always in connection with mind which is more ordinary than a visual look [18].

\section{THE PRINCIPLES OF ORGANIZING ARCHITECTURE LANDSCAPE}

Perceiving of the observer and enjoying of the near atmosphere is related to two factors, first: necessity of producing temptation of new experience and secondly: the necessity of knowing the design. First is the answer to these variations and the second principle is answering the permanents. These answers require 
paradox. Feeling requires variation and new information and at the same time searches for security in arrangement and repetition which is a similar model that has an unpredictable variation and will provide beautiful satisfaction [19].

In all fields of designing the arrangement of components are important. For arranging the models, designers have sorted special principles [20].

Presenting the principles follow three rows. First the primary elements that the whole landscapes are made by them (main elements). Each of these main elements may come with different methods (variations). These elements may be organized with different methods (organization). The combination of these three areas, their varieties and arrangements explain these models which could be found in the existing landscape or create new visual models [2].

The fundamental elements: period, line, surface, limited volume and open volume.

Variations: amount, location, direction, size, shape (form), sequence, tissue, density, color, time, light, the forces of vision and exertion vision.

\section{ORGANIZING}

Goals: variation, uniting, place feeling.

Spatial signs: nearness, limitation, combination, permanence, similarity, shape and context.

Constructive elements: assonance, confront, rhythm, proportion, criterion.

Arranging: axis, polarity, sequence, element and the adapted shape [2] (Table 3).

The aim of using the principles of beauty in designing is reaching to a united and arranged part. Feeling the united in designing is an exclusive emotion that is resulted from the combination of arrangements. Each part is the other part compliment and even with their differences, they are a united system. Reaching to uniqueness in designing with using the principles of beauty which mean: simplicity, variation, emphasis, balance, criterion sticking to the visual features arose from physical characteristics of producing designs which are: form, tissue and color [16]. That each of these factors is known as a quality of music.

\section{CONCLUSION}

In fact, music produces a kind of space in mind by organizing the sounds and art of melody producing that is called music scene. In other words, these qualities are certified as how these sound managements next to each other produce music scene and appear the beauty in mind.

The qualities of designing landscape and perception aspects of atmosphere and landscape well shown and each of the mentioned principles in organizing the landscape architecture, are known as principles of beauty and vision. The principles that following them in the process of designing will provide acceptable organizing. These principles in music are also grouped in principles of beauty and qualities of music in a way that equivalent of these principles in landscape and music are analyzed to help us reaching to the meaning. When these principles are used in principles of designing and organizing of landscape architecture beauty, there are exactly base principles in music to produce the musical sounds and as a result musical qualities are taken into account in landscape architecture.

\section{APPENDIX}

1) Arthur Schopenhauer

2) Suite which means bead consists of some components that are written in Tonality and mostly they own dance rhythms and can have different characters [14].

\section{REFERENCES}

L. Abolghasemi. The assembly of greenbelt of Tehran. Tehran: garden. 1992.

S. Bell. The Elements of Designing Visual in Landscape. Tehran: Tehran University Publ. 2008. 
F. Ching. Architecture; Form, Space and Order. New Jersey: John Wiley \& sons, Inc. 2007.

C. Dee. Form and Criterion and Landscape Architecture, Introduction. Tehran: Mehrazan. 2011.

M. Falamaki. Architecture and Music. 3rd Ed. Tehran: Space Publ. 2008.

Ch. Fitter. Poetry, Space, Landscape: Toward a New Theory. England: Cambridge University Press. 1995.

F. Habib, Designing Urban Landscape in History, Urbanization Introduction and Architecture. 48-53, 2006.

G. Hanoch-Roe. "Musical space and architectural time: Open scoring versus linear processes." International

Review of the Aesthetics and Sociology of Music. 145-160, 2003.

B. Hoseini,. Razzaghi, S. Movement and Time in Urbanization. Elmo sanat University of Iran, Eng Architect. 19, P. 83-88, 2008.

T. Kamal Poor. Tehran: Cheshme Publication. 2008.

C. Kent, Exploring on Landscape in Europe. Tehran: Terme Publication. 1991.

S.A. Mansouri. What is Urban Landscape? Analyzing the Historic Variations in Iran, the Magazine of Landscape. 9 (4). P. 30-33, 2010.

J.L. Matlack. Introduction to Designing Atmosphere and Landscape. Tehran: Parks and Landscape Organization. 2000.

B. Nafari. The Information of Music. 7th Ed. Tehran: Marlik Publication. 1998.

Okhovvat. Iranian Music and Decorative Arts. The magazine of beautiful arts. 16, 101-111, 2004.

H. Phalavan. Designing and Engineering in Nature (First cover: Managing and Designing). Tehran: Fadak Isatis Publication. 2011.

J. Rahmani,. M. Matlabi. Dictionary of Landscape. Tehran: Aftab Graphic Publication. 2005.

H. Razzaghi, The Analysis of Atmosphere and Urban Landscape and The Model of Users of Atmosphere

(Case study: around the River of Karaj). The Geography Research Journal. 4, 95-112, 2013.

G.W. Reid. Context to Form of Designing Landscape Architecture. Tehran: sadr. 2008.

G.H. Roohani. Designing Garden and Greenbelt. 2nd Ed. Tehran: Farhange Jame Publication. 1992.

H. Sattari Sarbangholi,. M. Shahed. Analyzing the Meaning of Iranian Music and Iranian Gardening Architecture. Architecture Urban Arman Shahr J. 9, 97-110, 2012.

A.L. Sayaf Zade,. M. Mirei,. M. Noode Farehani. The Role of Urban Landscape in Social Life and Citizens Local Identifications (Case study: Navab Highway). Science Research of Islamic Journal. 11, P. 29-39, 2013. S. Seyed,. A. Seyed. Architecture of Greenbelt (Landscaping). 2nd Ed. Tehran: Simaye Danesh Publication. 2010.

F. Seyfoddini. Urban Landscape. Tehran: Ayizh Publication. 2012.

P. Sheard. What is Architecture? Introduction to Designing Landscape, Constructing and Motors. Tehran: Fan Avaran Publication. 2006.

T. Sheridan,. L. Karen Van. "Hearing architecture: Exploring and designing the aural environment." Journal of Educator Architecture. 57.2, 37-44, 2003.

M. Tabatabaie. The Criterions of Urban and Atmosphere in Different Spatial Criterions. Journal of Exploration Urban. 17, 66-76, 2006. 